\title{
From Gospel to Law: The Lutheran Reformation and Its Impact on Legal Culture
}

\author{
JOHN WITTE JR ${ }^{1}$ \\ Robert Woodruff University Professor of Law, McDonald Distinguished Professor and \\ Director of the Center for the Study of Law and Religion at Emory University
}

\begin{abstract}
The Lutheran Reformation transformed not only theology and the Church but also law and the State. Despite his early rebuke of law in favour of the gospel, Martin Luther eventually joined up with various jurists and political leaders to craft ambitious legal reforms of Church, State and society on the strength of his new theology, particularly his new two-kingdoms theory. These legal reforms were defined and defended in hundreds of monographs, pamphlets and sermons published by Lutheran writers from the 1520 onwards. They were refined and routinised in equally large numbers of new Reformation ordinances that brought fundamental changes to theology and law, Church and State, marriage and family, criminal law and procedure, and education and charity. Critics have long treated this legal phase of the Reformation as a corruption of Luther's original message of Christian freedom from the strictures of all human laws and traditions. But Luther ultimately realised that he needed the law to stabilise and enforce the new Protestant teachings. Radical theological reforms had made possible fundamental legal reforms, which, in turn, would make those theological reforms palpable. In the course of the 1530 and thereafter, the Lutheran Reformation became in its essence both a theological and a legal reform movement. It struck new balances between law and gospel, rule and equity, order and faith, and structure and spirit.
\end{abstract}

Keywords: Luther, Reformation, law, society, two kingdoms

\section{INTRODUCTION}

On 10 December 1520, Martin Luther burned the canon law books of the Catholic Church. A large group of students and colleagues gathered in Wittenberg for the book-burning. Consigned to the flames were Gratian's Decretum of 1140 and four thick books of later papal laws. Also cast into the fire were a standard confessional book and several tomes on Catholic sacramental theology. 'This might as well go, too', Luther muttered, as he threw into the fire the papal bull that threatened his excommunication for heresy. He would later write of his canonical bonfire: 'I am more pleased with this than any other action in my life. ${ }^{2}$

1 This article is based on a lecture given at the Law and Religion Centre of Cardiff University on 2 December 2016 and is adapted from J Witte Jr, Law and Protestantism: the legal teachings of the Lutheran Reformation (Cambridge, 2002), and from a short article of the same name in $\mathrm{T} A$ Howard and M A Noll (eds), Protestantism After 500 Years (Oxford, 2016), pp 52-74.

2 J Pelikan and H T Lehmann (eds), Luther's Works, 55 vols (Philadelphia, PA, 1955-1986), vol XLVIII, pp 186-192 (hereafter $L W$ ). 
If there were a single event that signalled Luther's permanent break with Rome, this was it. Three years before, on 31 October 1517, Luther had posted his 95 Theses. As is well known, there he had attacked the church's crass commercialisation of salvation through the sale of indulgences. In several publications and debates in the next year he had challenged the biblical integrity of the church's theology of salvation and the sacraments. On 8-9 October 1518, Luther had answered a summons to appear in Augsburg before the Pope's representative, Cardinal Cajetan, but had refused to recant his views. On 28 November that year, he had appealed directly to the Pope, insisting upon his rights, as a professor of theology, to an open hearing of his views at a general church council. From 4 to 14 July 1519, with no such council forthcoming, Luther had engaged in a sensational public debate at the University of Leipzig with the Catholic theologian Johann Eck over fundamental questions of ecclesiastical authority - a debate that revealed the increasing radicalism of Luther's theological doctrines of justification by faith, the primacy of the Bible, the nature of the Church and the priesthood of all believers. ${ }^{3}$

By then, however, Pope Leo X had issued his bull of excommunication, Exsurge, Domine, condemning Luther and his followers:

Arise, O Lord, and judge your own cause. Remember your reproaches to those who are filled with foolishness all through the day. Listen to our prayers, for foxes have arisen seeking to destroy the vineyard whose winepress you alone have trod. When you were about to ascend to your Father, you committed the care, rule and administration of the vineyard, an image of the triumphant church, to Peter, as the head and your vicar and his successors. The wild boar from the forest seeks to destroy it and every wild beast feeds upon it. ... Against the Roman Church, lying teachers are rising, introducing ruinous sects, and drawing upon themselves speedy doom. Their tongues are fire, a restless evil, full of deadly poison. They have bitter zeal, contention in their hearts, and boast and lie against the truth. ${ }^{4}$

The bull went on to condemn the heretical teachings of that 'wild boar' Martin Luther as 'scandalous', 'offensive', 'seductive' and 'repugnant to Catholic truth'. It gave him 60 days after receipt to recant and return to the Catholic fold. The sixtieth day was 10 December 1520. On that day, Luther had his bonfire, burning his last bridge with Rome.

3 S Hendrix, Luther and the Papacy: stages in the Reformation conflict (Philadelphia, PA, 1981); M Brecht, Martin Luther, trans J L Schaaf (Philadelphia, PA, 1985-1993).

4 C Mirbt (ed), Quellen zur Geschichte des Papsttums und des römischen Katholizimus (second edition, Tübingen, 1911), pp 183-185. 
Luther based his attack on a radical new theology of freedom: freedom of the Church from the tyranny of the Pope, freedom of the laity from the hegemony of the clergy, freedom of the conscience from the strictures of canon law. 'Freedom of the Christian' was the rallying cry of the early Lutheran Reformation. ${ }^{5}$ It drove theologians and jurists, clergy and laity, princes and peasants alike to denounce the Church's legal strictures and structures with unprecedented alacrity. 'One by one, the structures of the church were thrust into the glaring light of the Word of God and forced to show their true colors', wrote Jaroslav Pelikan. ${ }^{6}$ Few Church structures survived this scrutiny in the heady days of the 1520s. The Church's canon law books were burned. Church courts were closed. Monasteries were confiscated. Benefices were dissolved. Church properties were seized. Clerical privileges were stripped. Mendicant begging was banned. Mandatory celibacy was suspended. Indulgence trafficking was condemned. Taxes to Rome were outlawed. Ties to the Pope were severed. The German people who followed Luther were now to live by the pure light of the Word of God and the simple law of the local community.

Although such attacks built on two centuries of reformist agitation in the West, it was especially Luther's theological teachings that ignited this movement in Germany. Luther taught that salvation comes through faith in the gospel, not through works of the law. All persons stand directly before God; they are not dependent upon clerics for divine mediation. All believers are priests to their peers; they are not divided into a higher clergy and lower laity. All persons are called by God to serve in vocations; clerics are not the only ones with a Christian calling. The Church is a communion of saints, not a corporation of law. The consciences of its members are guided by the Bible, not governed by traditions. The Church is called to serve society in love, not to rule it by law. Law is the province of the magistrate, not the prerogative of the cleric. When put in such raw and radical terms, these theological doctrines of justification by faith, the priesthood of believers, law and gospel, and others were highly volatile compounds. When sparked by Luther's pugnacious rhetoric and relentless publications, they set off a whole series of explosive reforms in various parts of central Europe.

In these early years, Luther's attack on the Church's canon law and clerical authority sometimes broadened into an attack on human law and human authority in general. Luther famously wrote in 1520 : 'Neither pope nor bishop nor any other man has the right to impose a single syllable of law upon a Christian man without his consent.' The Bible contains all the law that is needed for proper Christian living. To subtract from the law of the Bible is blasphemy. To add to the law of the Bible is tyranny. 'Wise rulers, side by side with 
Holy Scripture, [are] law enough.' When jurists of the day objected that such radical biblicism was itself a recipe for blasphemy and tyranny, Luther turned on them harshly. 'Jurists are bad Christians', he declared repeatedly. 'Every jurist is an enemy of Christ.' When the jurists persisted in their criticisms, Luther reacted with vulgar anger: 'I shit on the law of the pope and of the emperor, and on the law of the jurists as well. ${ }^{7}$

The rapid deconstruction of law, politics and society that followed upon such shrill rhetoric plunged Germany into an acute crisis in the 1520 s and 1530 s. Luther had drawn too sharp a contrast between freedom and order within the Church. Young Lutheran churches and clerics were treating their new liberty as licence for all manner of doctrinal and liturgical experimentation and laxness. Widespread confusion reigned over preaching, prayers and pastoral duties. Church attendance, tithe payments and charitable offerings declined abruptly among many who took literally Luther's new teachings of free grace. Many radical social experiments were engineered out of his doctrines of the priesthood of believers and justification by faith.

Moreover, Luther had driven too deep a wedge between canon law and civil law. Many subjects traditionally governed by the Church's canon law remained without effective legal guidance. The vast Church properties that local magistrates had confiscated were disappearing rapidly into private coffers. Drunkenness, usury and vagabondage reached new heights. Crime, delinquency and mendicancy soared. Schools, charities and hospitals closed down. Marriage, divorce and inheritance became hopelessly confused. Widows, orphans and the poor were dying in the streets. All these subjects, and many more, the Catholic canon law and Church institutions had governed in detail for many centuries in Germany. The new Protestant civil law, where it existed at all, was too primitive to address these subjects properly.

In response, the Lutheran reformation of theology and the Church quickly broadened into a reformation of law and the State as well. Deconstruction of the canon law for the sake of the gospel gave way to reconstruction of the civil law on the strength of the gospel. Castigation of Catholic clerics as self-serving overlords gave way to cultivation of Protestant magistrates as fathers of the community called to govern on God's behalf. Old rivalries between theologians and jurists gave way to new alliances, especially in the new Lutheran universities.

In the 1530 s and thereafter, Lutheran theologians began to pay much closer attention to the legal, political and social implications of their new teachings. They joined Lutheran jurists to craft ambitious legal reforms of Church, State and society. These legal reforms were defined and defended in hundreds of 
new writings published by Lutheran theologians and jurists from the 1530 s to the 1560 s. They were refined and routinised in hundreds of new reformation ordinances promulgated by German cities, duchies and territories that converted to the Lutheran cause.

Critics of the day, and ever since, have criticised this legal turn of the Reformation as a corruption of the original Lutheran message. For some, it was a bitter betrayal of the new freedom and equality that Luther had promised. For others, it was a distortion of Luther's fundamental reforms of theology and Church life. For still others, it was a simple reversion to Catholic canonical norms dressed in new theological forms.

Whatever the merits of such criticisms in Luther's day, it was the combination of theological and legal reforms that rendered the Lutheran Reformation so resolute and resilient. The reality was that Luther and the theologians needed the law and the jurists, however much they scorned them initially. It was one thing to deconstruct the framework of mediaeval Catholic law, politics and society with a sharp theological sword. It was quite another thing to reconstruct a new Lutheran framework of law, politics and society with only this theological sword in hand. Luther learned this lesson the hard way in the crisis years of the 1520 s and 1530s, and it almost destroyed the early Protestant movement. He quickly came to realise that law was not just a necessary evil but also an essential blessing in this earthly life.

It was thus both natural and necessary for the Lutheran Reformation to move from theology to law. Radical theological reforms had made possible fundamental legal reforms. Fundamental legal reforms, in turn, would make permanent radical theological reforms. The Lutheran Reformation became in its essence both a theological and a legal reform movement. It struck new balances between law and gospel, order and faith, structure and spirit. And it offered new theories and laws of Church and State, marriage and education that have become a permanent legacy of the Western tradition.

\section{LUTHER'S TWO-KINGDOMS THEORY}

The starting point for this combined theological and legal movement was Luther's complex theory of the two kingdoms. This theory came together in his mind in the later 1520 s and 1530s, and became a dominant gene in the genetic code of Lutheran theology and jurisprudence thereafter. Luther argued that God has ordained two kingdoms or realms in which humanity is destined to live: the earthly kingdom and the heavenly kingdom. The earthly kingdom is the realm of creation, of natural and civil life, where a person operates primarily by reason and law. The heavenly kingdom is the realm of redemption, of spiritual and eternal life, where a person operates primarily by faith and love. These two kingdoms embrace parallel heavenly and earthly, spiritual and temporal 
forms of righteousness and justice, government and order, truth and knowledge. But the two kingdoms ultimately remain distinct. The earthly kingdom is distorted by $\sin$ and governed by the law. The heavenly kingdom is renewed by grace and guided by the gospel. A Christian is a citizen of both kingdoms at once and invariably comes under the distinctive government of each. As a heavenly citizen, the Christian remains free in his or her conscience, called to live fully by the light of the word of God alone. But as an earthly citizen, the Christian is bound by law, and is called to obey the natural orders and offices that God has ordained for the governance of this earthly kingdom. ${ }^{8}$

Luther's two-kingdoms theory was a rejection of traditional hierarchical theories of being, society and authority. For centuries, the Catholic Church had taught that God's creation was hierarchical in structure - a vast chain of being emanating from God and descending through various levels and layers of reality. In this great chain of being, each creature found its place and its purpose, and each human society found its natural order and hierarchy. It was thus simply the nature of things that some persons and institutions were higher on this chain of being and some were lower. It was the nature of things that some were closer and had more ready access to God, and some were farther away and in need of greater mediation in their relationship with God. This chain-of-being theory, which some will recognise in Dante's Divine Comedy, was one basis for traditional Catholic arguments for the superiority of the Pope to the emperor, of the clergy to the laity, of the canon law to the civil law, of the Church to the State. ${ }^{9}$

Luther's two-kingdoms theory turned this traditional ontology on its side. By distinguishing the two kingdoms, he highlighted the radical separation between the Creator and the creation, and between God and humanity. For Luther, the fall into sin destroyed the original continuity and communion between the Creator and the creation, the organic tie between the heavenly kingdom and the earthly kingdom. There was no series of emanations of being from God to humanity. There was no stairway of merit from humanity to God. There was no purgatory. There was no heavenly hierarchy. God is present in the heavenly kingdom, and is revealed in the earthly kingdom mainly through 'masks'. Persons are born into the earthly kingdom and have access to the heavenly kingdom only through faith. ${ }^{10}$

8 See detailed sources for this section in Witte, Law and Protestantism, pp 87-118.

9 See A Lovejoy, The Great Chain of Being: a study of the history of an idea (Cambridge, MA, 1936). On the legal and ecclesiological implications of this ontology, see B Tierney, Religion, Law, and the Growth of Constitutional Thought: 1150-1650 (Cambridge, 1982), pp 8ff.

$10 L W$, vol I, pp 66ff, 52; LW, vol LII, pp 57, 79; WA, vol VII, p 73; LW, vol XXXIII, pp 295ff; WA TR, vol I, no 71; LW, vol LIV, p 71; LW, vol XXVI, pp 94-96; LW, vol XIV, p 114; LW, vol XXIV, p 67; LW, vol XXVI, pp 95-96; WA, vol XXXI, part 1, p 437; WA, vol XL, part 3, pp 271ff. 
Luther did not deny the traditional view that the earthly kingdom retained its natural order, despite the fall into sin. There remained, in effect, a chain of being, an order of creation that gave each human being and institution its proper place and purpose in this life. But, for Luther, this chain of being was horizontal, not hierarchical. Before God, all persons and all institutions in the earthly kingdom were by nature equal. Luther's earthly kingdom was a flat regime, a horizontal realm of being, with no person and no institution obstructed or mediated by any other in relationship to and accountability before God.

\section{SOCIAL, POLITICAL AND LEGAL REFORMS}

Luther's two-kingdoms theory also turned the traditional hierarchical theory of human society on its side. For many centuries, the Church had taught that the clergy were superior to the laity. The clergy were special officers of the higher heavenly realm of grace, while the laity were simply members of the lower earthly realm of nature. As members of the higher heavenly realm, the clergy had readier access to God and God's mysteries. They thus mediated the channel of grace between the laity and God - dispensing God's grace through the sacraments and preaching, and interceding for God's grace by hearing confessions, receiving charity and offering prayers on behalf of the laity. In this sense, the lowliest cleric was superior to the noblest emperor. All the clergy, from the lowliest parson to the greatest pope, were exempt from earthly laws, taxes and other duties, and foreclosed from earthly pursuits such as marriage and family life.

Luther rejected this hierarchical social theory. Clergy and laity were fundamentally equal before God and before all others, he argued. His doctrine of the priesthood of all believers at once 'laicised' the clergy and 'clericised' the laity. It treated the traditional 'clerical' office of preaching and teaching as just one other vocation alongside many others that a conscientious Christian could properly and freely pursue. It treated all traditional 'lay' offices as forms of divine calling and priestly vocation, each providing unique opportunities for service to one's peers. Preachers and teachers of the visible Church must carry their share of civic duties and pay their share of civil taxes, just like everyone else. And they may and should participate in earthly activities such as marriage and family life, just like everyone else."

Luther expanded on this natural egalitarianism with his robust understanding of the Christian 'calling' (Beruf) or 'vocation' (vocatio). He believed that every 'good, decent and useful' occupation in which a Christian conscientiously 
engages should be treated as a Christian vocation. Each vocation was an equally virtuous and effective calling of God, though none was a pathway to salvation. The carpenter and the prince, the mineworker and the judge, the housewife and the banker - all should accept their Christian responsibility to perform their tasks conscientiously and, so far as possible, in the service of God and others. ${ }^{12}$ Public officials, in particular, Luther argued, have a special calling to serve the community. This calling might require them to adopt a Christian social ethic that differs from a Christian personal ethic. A Christian's duty in his or her direct relationship with God 'as a private person, a person for himself alone', is to love his or her enemy and to suffer injustice and abuse from his or her neighbour without resistance and without revenge. As a public person, serving in such offices as the military or the judiciary, however, a Christian might well be required to resist his or her neighbour and to avenge injustice and abuse, even to the point of violence and bloodshed. ${ }^{13}$

Luther did not press his natural egalitarianism to communitarian extremes. He saw no incompatibility between insisting on the equal status of all persons and vocations before God and accepting the ample disparities in wealth, power, privilege and respectability among persons and positions in daily life. Some are more blessed, some less so. Some work harder, some play more. Some enjoy goods, some spurn them. Some start with noble inheritances, some start with nothing. Some vocations require more pageantry and property than others. None of these empirical disparities, however, changes the fundamental reality of human equality before God.

\section{Political reforms}

Luther's two-kingdoms theory also turned the traditional hierarchical theory of spiritual and temporal authority on its side. For centuries, the Church had taught that the Pope is the vicar of Christ, in whom Christ has vested the 'plenitude of his power'. This power was symbolised in the 'two swords' discussed in the Bible (Luke 22:38): the spiritual and the temporal swords. Christ had handed these two swords to the highest being in the human world - the Pope, the vicar of Christ. The Pope and his clerical delegates wielded the spiritual sword, in part by establishing canon laws for the governance of all of Christendom. The Pope, however, was too holy to wield the temporal sword. He thus delegated this sword to those authorities below the spiritual realm: emperors, kings, dukes and their civil retinues. These civil magistrates were to promulgate and enforce civil laws in a manner consistent with canon law and other Church teachings. Under this two-swords theory, civil law was by its nature inferior to canon

12 See detailed sources and discussion in G Wingren, The Christian Calling: Luther on vocation, trans C C Rasmussen (Philadelphia, PA, 1957).

13 LW, vol XLVI, pp 93ff; LW, vol XXI, pp 108-115; LW, vol XLVI, pp 93-99. 
law. Civil jurisdiction was subordinate to ecclesiastical jurisdiction. Political authority was subordinate to clerical authority. Mediaeval popes could rarely make good on these grand claims to universal, pre-emptory legal authority in Christendom. Indeed, the strongest expressions of the two-swords theory came in the late Middle Ages, when the papacy was losing its power and clutching ever more firmly to a waning ideal. But the two-swords theory remained a staple of traditional political theory in Germany. And a good number of strong German bishops and ecclesiastical princes in Luther's day were still making good on its claims in their local polities. ${ }^{14}$

Luther rejected this hierarchical view of government. For him, the earthly kingdom featured three natural forms and forums of government: the domestic, ecclesiastical and political estates - or, in modern terms, the family, the Church and the State. These three institutions stood equal before God and were each called directly by God to discharge complementary tasks in the earthly kingdom. The family was called to rear and nurture children, to teach and to discipline them, and to cultivate and exemplify love and charity within the home and the broader community. The Church was called to preach the Word, to administer the sacraments and to discipline its wayward members. The State was called to protect peace, to punish crime, to promote the common good and to support the Church, the family and other institutions derived from them.

Luther argued that not only were these three estates equal, rather than hierarchical, in authority, status and responsibility, but only the State had legal authority - the authority of the sword to pass and enforce positive laws for the governance of the earthly kingdom. Contrary to the two-swords theory, he emphasised that the Church was not a law-making authority. The Church had no sword. It had no jurisdiction. It had no business involving itself in the day-to-day administration of law or in the vesting of magistrates in their offices. The Church's ministry and mission lay elsewhere. Each local church needed internal rules of order and discipline to govern its members and officers, and external legal structures to protect its polity and property. But it was up to the local magistrate to pass and enforce these ecclesiastical laws, in consultation and co-operation with the local clergy and theologians. And Church officers and theologians had to be vigilant in preaching and teaching the law of God to magistrates and subjects alike, and in pronouncing prophetically against injustice, abuse and tyranny. But formal legal authority lay with the State, not with the Church. ${ }^{15}$

Luther was more concerned with the function than with the form of the State. At first, he had hoped that the emperor would endorse the Reformation, and pp 7-21; E Lewis, Medieval Political Ideas (New York, 1954), vol II, pp 506-538.

15 LW, vol XLV, pp 105ff; LW, vol XXXVI, pp $106 \mathrm{ff}$. 
accordingly included in his early writings some lofty panegyrics on the imperial authorities of the Holy Roman Empire of his day and of the Christian Roman Empire of a millennium before. When the emperor failed him, Luther turned at various times to the nobility, the peasantry, the city councils and the princes, and in turn wrote favourably about each of them, and then sometimes unfavourably when they failed him. ${ }^{16}$ Such writings must be read in their immediate political context, however, and not used to paint Luther as a theorist of political absolutism, or elitist oligarchy or constitutional democracy. He had no firm or consistent theory of the forms of political office. He did not sort out systematically the relative virtues and vices of monarchy, aristocracy or democracy. He spent very little time on the thorny constitutional questions of the nature and purpose of executive, legislative and judicial powers, let alone finer questions of checks and balances, conflict of laws, judicial review and other such topics that occupied other sixteenth-century Protestant and humanist writers. These were not Luther's primary concern.

Luther was more concerned with the general status and function of the political office - both before God and within the community. On the one hand, he believed, the magistrate was God's vice-regent in the earthly kingdom, called to elaborate and enforce God's Word and will, to reflect God's justice and judgment on earthly citizens. The magistracy was, in this sense, a 'divine office', a 'holy estate', a 'Godly calling', within the earthly kingdom. Indeed, the magistrate was a 'god' on earth (as Psalm 82:6 put it), to be obeyed as if God Himself. 'Law and earthly government are a great gift of God to mankind', Luther wrote with ample flourish. 'Earthly authority is an image, shadow, and figure of the dominion of Christ.' Indeed, 'a pious jurist' who served faithfully in the Christian magistrate's retinue was 'a prophet, priest, angel, and savior ... in the earthly kingdom'. ${ }^{17}$ The magistrate and his retinue not only represented God's authority and majesty, however; they also exercised God's judgment and wrath against human sin. Luther wrote that 'Princes and magistrates are the bows and arrows of God', equipped to hunt down God's enemies in the earthly kingdom. The hand of the Christian magistrate, judge or soldier 'that wields the sword and slays is not man's hand, but God's; and it is not man, but God, who hangs, tortures, beheads, slays, and fights. All these are God's works and judgments. ${ }^{18}$

On the other hand, Luther believed, the magistrate was the 'father of the community' (Landesvater or paterpoliticus). He was to care for his political subjects as if they were his children, and his political subjects were to 'honour' him as if he

16 See texts in K Trüdinger, Luthers Briefe und Gutachten an weltliche Obrigkeit zur Durchfuhrung der Reformation (Münster, 1975); J M Porter (ed), Luther: selected political writings (Philadelphia, PA, 1974).

17 See Porter, Luther, and further texts in LW, vol II, pp 139ff; LW, vol XIII, pp 44ff; LW, vol XLIV, pp 92ff; LW, vol XLV, pp 85ff; LW, vol XLVI, pp 237ff; WA, vol XXX, part 2, p 554 .

18 LW, vol XVII, p 171; LW, vol XLV, p 113; LW, vol XLVI, pp 95ff; WA, vol VI, p 267; WA, vol XIX, p 626. 
were their parent. This was the essence of the proper authority, Obrigkeit or ordo politicus, of the political authorities and their subjects that constitute 'the State'. Like a loving father, the magistrate was to keep the peace and to protect his subjects from threats or violations to their persons, properties and reputations. He was to deter his subjects from abusing themselves through drunkenness, sumptuousness, prostitution, gambling and other vices. He was to nurture and sustain his subjects through the community chest, the public almshouse and the State-run hospice. He was to educate them through the public school, the public library and the public lectern. He was to see to their spiritual needs by supporting the ministry of the locally established church, and by encouraging their attendance and participation through the laws of Sabbath observance, tithing and holy days. He was to see to their material needs by reforming inheritance and property laws to ensure more even distribution of the parents' property among all children. He was to set an example of virtue, piety, love and charity in his own home and private life for his faithful subjects to emulate and to respect. The Christian magistrate was to complement and support the God-given responsibilities of parents and family members for their children and dependants, without intruding on the paternal office. And he was to support the preaching and sacramental life of the local church without trespassing on the ecclesiastical office, let alone that of the invisible Church of the heavenly kingdom. ${ }^{19}$

These twin metaphors of the Christian magistrate - as the lofty vice-regent of God and as the loving father of the community - described the basics of Luther's and, later, Lutheran political theory. For Luther, political authority was divine in origin but earthly in operation. It expressed God's harsh judgment against sin but also His tender mercy for sinners. It communicated the law of God but also the lore of the local community. It depended upon the Church for prophetic direction but it took over from the Church all jurisdiction - governance of marriage, education, poor relief and other earthly subjects traditionally governed by the Catholic Church's canon law. Either metaphor standing alone could be a recipe for abusive tyranny or officious paternalism; but both metaphors together provided Luther and his followers with the core ingredients of a robust Christian republicanism and a budding Christian welfare state.

\section{Legal reforms}

Luther's two-kingdoms theory effectively 'flattened' the traditional hierarchical theories of being and order, of clergy and laity, of ecclesiastical and political authority. His earthly kingdom was a horizontal realm, with each person, each order and each official called directly by God to discharge discrete offices and 
vocations. What kept this earthly kingdom and its activities intact was the law of God and its elaboration by earthly authorities and subjects.

Luther defined the law of God as the set of norms ordained by God in the creation, written by God on the hearts of all persons and rewritten by God on the pages of the Bible. Luther called this variously the 'law of nature', 'natural law', 'divine law', 'Godly law', 'the law of the heart', 'the teachings of conscience' and 'the inner law', among others - terms and concepts that he did not clearly differentiate either from each other or from traditional formulations. ${ }^{20}$ His main point was that God's natural law, set at creation, continued to operate after the fall into sin, and that it provided the foundation for all positive law and public morality in the earthly kingdom.

The natural law defined the basic obligations that a person owed to God, neighbour and self. For Luther, the clearest expression of these obligations was the Ten Commandments, which God inscribed on two tables and gave to Moses on Mount Sinai. The First Table of the Decalogue set out basic obligations to honour the Creator God, to respect God's name, to observe the Sabbath and to avoid idolatry and blasphemy. The Second Table set out basic obligations to respect one's neighbour: to honour authorities, and not to kill, commit adultery, steal, bear false witness or covet. Luther believed this to be a universal statement of the natural law, binding not only on the Jews of the Old Testament but also on everyone. 'The Decalogue is not the law of Moses ... but the Decalogue of the whole world, inscribed and engraved in the minds of all men from the foundation of the world.' Or again:

whoever knows the Ten Commandments perfectly must know all the Scriptures, so that, in all affairs and cases, he can advise, help, comfort, judge, and decide both spiritual and temporal matters, and is qualified to sit in judgment upon all doctrines, estates, spirits, laws, and whatever else is in the world.

And again: 'although the Decalogue was given in a particular way and place and ceremony ... all nations acknowledge that there are sins and iniquities'. ${ }^{21}$

Luther argued that knowledge of this natural law comes not only through revealed scripture but also through natural reason - one of those 'masks' by which the hidden God is partly revealed in the earthly kingdom. He built on St Paul's notion that even the heathens have a 'law written in their hearts, their conscience also bearing witness' to a natural knowledge of good and evil 
(Romans 2:15). Every rational person thus 'feels' and 'knows' the law of God, even if only obliquely. The basic teaching of the natural law

lives and shines in all human reason, and if people would only pay attention to it, what need would they have of books, teachers, or of law? For they carry with them in the recesses of the heart a living book which would tell them more than enough about what they ought to do, judge, accept, and reject. ${ }^{22}$

But sinful persons do not, of their own accord, readily heed the natural law written on their hearts and rewritten in the Bible. Thus God has called upon other persons and authorities in the earthly kingdom to elaborate its basic requirements. All Christians, as priests to their peers, must communicate the natural law of God by word and by deed. Parents must teach it to their children and dependants. Preachers must preach it their congregants and catechumens. And magistrates must elaborate and enforce it through their positive laws and public policies.

Luther believed that the magistrate's elaboration and enforcement of the natural law was particularly important, since only the magistrate held formal legal authority in the earthly kingdom. 'Natural law is a practical first principle in the realm of public morality', he wrote; 'it forbids evil and commands good. Positive law is a decision that takes local conditions into account', and 'credibly' elaborates the general principles of the natural law into specific precepts to fit these local conditions. 'The basis of natural law is God, who has created this light, but the basis of positive law is the earthly authority', the magistrate, who represents God in this earthly kingdom. The magistrate must promulgate and enforce these positive laws by combining faith, reason and tradition. $\mathrm{He}$ must pray to God earnestly for wisdom and instruction. He must maintain 'an untrammeled reason' in judging the needs of his people and the advice of his counsellors. He must consider the wisdom of the legal tradition - particularly that of Roman law, which Luther called a form of 'heathen wisdom'. 'The polity and the economy' of the earthly kingdom 'are subject to reason. Reason has first place. There [one finds] civil laws and civil justice. ${ }^{.23}$

But Luther insisted that both natural law and positive law had to be applied equitably. 'The strictest law [can do] the greatest wrong', he wrote, citing Cicero. Thus 'equity is necessary' in the application of rules of all sorts, whether in the State or in the Church, in the household or in the classroom. Any ruler, whatever his or her office, 'who does not know how to dissemble

23 WA TR, vol III, no 3911; WA, vol XII, p 243; WA, vol XIV, pp 591, 714; WA, vol XVI, p 537; WA, vol $\mathrm{XXX}$, part 2, p 557; WA, vol XL, p 305; WA, vol LI, pp 211, 241-242; LW, vol XLV, pp 120-126. 
does not know how to rule', Luther said pithily. 'This is what is meant by [doing] equity (epiekeia).' Luther argued that to apply a rule equitably 'is not rashly to relax laws and discipline'. It is, rather, to balance firmness and fairness and to recognise circumstances that might mitigate against literal application of the rule or that might raise questions that the rule does not and perhaps should not reach. In such instances, 'equity will weigh for or against' strict application of the rule, and a wise ruler will know the juster course. 'But the weighing must be of such kind that the law is not undermined, for no undermining of natural law and divine law must be allowed. ${ }^{24}$

\section{Reforms of marriage and education}

Luther and his followers worked to reform not only Church and State but also marriage and the family, the third of his three natural estates. ${ }^{25}$ Prior to the sixteenth century, marriage was regarded as a sacrament of the Church. It was formed by the mutual consent of a fit man and a fit woman in good religious standing. It symbolised the enduring union of Christ and his Church, and conferred sanctifying grace upon the couple and their children. The parties could form this union in private, but once properly formed it was an indissoluble bond broken only by the death of one of the parties.

As a sacrament, marriage was subject to the jurisdiction of the mediaeval Church. A complex network of canon laws governed sex, marriage and family life in detail, from abortion to euthanasia. The Church did not regard the family as its most exalted estate, however. Although a sacrament and a sound way of Christian living, marriage (and with it, family life) was not considered to be spiritually edifying. Marriage was a remedy for sin, not a recipe for righteousness. It was considered subordinate to celibacy. Clerics and monastics were required to forgo marriage as a condition for ecclesiastical service. Those who could not were not worthy of the Church's holy orders and offices.

Lutheran theologians treated marriage not as a sacrament of the heavenly kingdom but as a social estate of the earthly kingdom. They taught that marriage was a natural institution that served the goods of mutual love and support of husband and wife, mutual procreation and nurture of children, and mutual protection of both spouses from sexual sin. All adult persons, preachers and others alike, should pursue the calling of marriage, for all were in need of the comforts of marital love and of protection from sexual sin. Moreover, the marital household served as a model of authority, charity and pedagogy in the earthly kingdom and as a vital instrument for the reform of Church, State and civil society.

24 WA TR, vol III, no 4178; LW, vol LIV, p 325; WA TR, vol I, no 315; LW, vol LIV, pp 43-44; WA, vol XIV, pp 667ff; LW, vol XLVI, p 100.

25 For detailed sources on this topic, see Witte, Law and Protestantism, pp 199-256, updated in J Witte Jr, From Sacrament to Contract: marriage, religion, and law in the Western tradition (second edition, Louisville, KY, 2012), pp 113-158. 
Parents served as 'bishops' to their children. Siblings served as priests to each other. The household as a whole was a source of evangelical and charitable impulses in society.

Though divinely created and spiritually edifying, however, marriage remained a social estate of the earthly kingdom. All parties could partake of this institution, regardless of their faith or lack of it. Though guided by biblical norms and clerical counselling, marriage and family life were subject to the rule of the State, not the Church. Civil magistrates were to set the laws for marriage formation, maintenance and dissolution; for child custody, care and control; and for family property, inheritance and commerce and more.

Lutheran magistrates rapidly translated this new Protestant gospel of marriage into civil law. They passed new civil marriage laws that shifted marital jurisdiction from the Church to the State. They strongly encouraged the marriage of clergy, discouraged celibacy and prohibited monasticism. They denied the sacramentality of marriage and the religious tests and spiritual impediments traditionally imposed on prospective marital couples. They simplified the doctrine of consent to betrothal and marriage, and required the participation of parents, peers, priests and political officials in the process of marriage formation and dissolution. They sharply curtailed the number of impediments to marriage. And they introduced absolute divorce on proof of adultery, desertion and other faults, with a subsequent right to remarriage, at least for the innocent party.

The Lutheran reformers soon extended their reforms to schools, which Luther called little churches, little states and little families rolled into one. ${ }^{26}$ Prior to the sixteenth century, schools were dominated by the Church. The mediaeval Church had established a refined system of religious education for Germany and beyond. Cathedrals, monasteries, chantries, ecclesiastical guilds and large parishes offered the principal forms of lower education, governed by general and local canon law rules of the Church. Gifted graduates were sent on to Church-licensed universities for advanced training in the core faculties of law, theology and medicine. The vast majority of students, however, were trained for clerical and other forms of service in the Church.

The Lutheran Reformation transformed this Church-based school system into a new system of public schools that allowed each youngster to prepare for his or her own distinctive Christian calling. In the reformers' view, the magistrate, as 'father of the community', was primarily responsible for the schooling of his political 'children'. Education was to be mandatory for boys and girls alike. It was to be fiscally and physically accessible to all. It was to be marked by both formal classroom instruction and civic education through community libraries, lectures and other media. The curriculum was to combine 
biblical and evangelical values with humanistic and vocational training. Students were to be stratified into different classes, according to age and ability, and slowly selected for any number of vocations. The public school was to be, in Philip Melanchthon's famous phrase, the 'civic seminary' of the commonwealth, designed to combine deep faith and deep learning. ${ }^{27}$ As the Reformation unfolded in Germany, the local Protestant magistrate replaced the local Catholic bishop as the chief protector and cultivator of the public school and university. The State's civil law replaced the Church's canon law as the chief law governing education. The Bible replaced the scholastic texts as the chief handbook of the curriculum. German replaced Latin as the universal tongue of the educated classes in Germany. The general callings of all Christians replaced the special calling of the clergy as the essence of education.

\section{THE CULTURAL AND LEGAL LEGACY OF THE LUTHERAN REFORMATION}

Nearly half a millennium after it first broke out in the little town of Wittenberg, the Lutheran Reformation still exerts influence on Western theology, law and culture. It is worth recounting the familiar but fundamental changes to German spiritual life born of the Reformation. It radically resystematised dogma. It truncated the sacraments. It revamped spiritual symbolism. It vernacularised the Bible and the worship service. It transformed corporate worship and congregational music. It gave new emphasis to the pulpit and the sermon. It expanded catechesis and religious instruction. It truncated clerical privileges and Church properties. It dissolved ecclesiastical foundations and endowments. It outlawed pilgrimages and the cult of religious artefacts. It rejected the veneration of non-biblical saints and the cult of the dead. It outlawed the payment of indulgences and mortuaries. It reduced the number of holy days. It lightened spiritual rules of diet and dress. It reformed ecclesiastical discipline and church administration, and much more. A leaner, cleaner, more participatory and more egalitarian Church emerged as a consequence.

This theological transformation is one of Germany's enduring legacies to the world. Lutheran and other churches around the world still hold firmly to many of the cardinal theological teachings of the Lutheran Reformation, and the great Lutheran catechisms, confessions and creeds forged in the Reformation era ring with as much power for many Christians today as they did for Lutherans in the 1520 s and ' 30 s. The hymns that Luther crafted still lift the rafters of many modern Protestant worship services. The art and woodcuts that Luther inspired still bring gasps to many modern museum visitors. The Lutheran masterpieces of Johann Sebastian Bach and his sons are, many feel, preludes to the music of 
heaven. The timeless language and phrases of Luther's German Bible and German Mass capture the imagination of a modern German as much as the magisterial language of the King James Bible and the Book of Common Prayer captures the imagination of a modern English-speaker.

Much of our modern Western law and politics still bears the unmistakable marks of the Lutheran Reformation. Today in every Western legal system and well beyond, we protect the freedom of conscience, for which Luther risked his life. And we have placed his original understandings of religious freedom, human dignity, liberty and equality at the cornerstones of our constitutional orders.

Today, in most Western legal systems, marriage is still viewed as both a civil and a spiritual institution, as Luther taught, whose formation and dissolution require special legal procedures. Parents must still consent to the marriages of their minor children. Peers must still attest to the veracity of the marital oath. Pastors or political officials must still confirm the marital union, if not consecrate it. Divorce and annulment still require a special public proceeding before a tribunal, with proof of support for dependent spouses and children.

Today, in most Western legal systems, basic education remains a fundamental right of the citizen to procure and a fundamental duty of the State to provide. Literacy and learning are still considered a prerequisite for individual flourishing and communal participation. Society still places a heavy burden on those who shirk education voluntarily. The State is still the essential monitor of civil education, which task it discharges directly through its own public or common schools, or indirectly through its accreditation and supervision of private schools.

Today, in most Western legal systems, care for the poor and needy remains an essential office of the State and an essential concern of the citizen. The rise of the modern Western welfare state over the past century is in no small measure a new institutional expression of the Lutheran ideal of the magistrate as the father of the community, called to care for all his political children. The concurrent rise of the modern philanthropic citizen is, in no small measure, a modern institutional expression of Luther's ideal of the priesthood of all believers, each called to give loving service to neighbours. Sixteenth-century Lutherans and twenty-first-century Westerners seem to share the assumption that the State has a role to play not only in fighting wars, punishing crime and keeping peace but also in providing education and welfare, fostering charity and morality, and facilitating worship and piety. They also seem to share the assumption that law has not only a basic use of coercing citizens to accept a morality of duty but also a higher use of inducing citizens to pursue a morality of aspiration.

Much of our modern Western struggle with law, however, is also part of the legal legacy of the Lutheran Reformation. For example, the Lutheran reformers removed the Church as the spiritual ruler of Germany in expression of their 
founding ideals of religious liberty. But they ultimately anointed the State as the new spiritual ruler of Germany in expression of their new doctrines of Christian republicanism. Ever since, Germany and other Protestant nations have been locked in a bitter legal struggle to come to grips with the legacy of state establishments of religion while also allowing religious freedom for all.

The Lutheran reformers removed the Pope, who, in their view, impugned the Christian conscience, fleeced the sheep of Christendom and reduced the German people to quivering obedience for fear of their eternal life. But the reformers ultimately anointed the secular prince as the new vice-regent of God on earth, the summus episcopus, with too few constitutional safeguards against his tyrannical excesses and too few intellectual resources to support civil disobedience, let alone political revolt.

The Lutheran reformers removed clerics as mediators between God and the laity, in expression of St Peter's teaching of the priesthood of all believers. But they ultimately interposed husbands between God and their wives, in expression of St Paul's teaching of male headship within the home. The reformers outlawed monasteries and cloisters. But these reforms also ended the vocations of many single women, placing a new premium on the vocation of marriage. Ever since, Protestant women have been locked in a bitter legal struggle to gain fundamental equality both within the marital household and without - a struggle that continues in more conservative Protestant communities today.

Luther's legal legacy, therefore, should be neither unduly romanticised nor unduly condemned. Those who champion Luther as the father of liberty, equality and fraternity might do well to remember his ample penchant for elitism, statism and chauvinism. Those who see the reformers only as belligerent allies of repression and abuse should recognise that they were also benevolent agents of education and welfare. Prone as he was to dialectic reasoning, and aware as he was of the inherent virtues and vices of human achievements, Luther would likely have reached a comparable assessment.

Such circumspection becomes doubly imperative in drawing connections between sixteenth-century Lutheranism and twentieth-century Nazism. It may be tempting to follow no small number of scholars who have drawn direct and easy lines from Luther to Hitler, from Luther's 1543 sermon On The Jews and Their Lies to Hitler's slaughter of the Jews in the ghettoes and the death camps. Such unfathomable tragedies as the Holocaust demand villains to render them a bit more understandable, and so giant a German personality as Luther is a natural and easy target to single out. ${ }^{28}$

But we need to remind ourselves of elementary facts and elementary law before drawing this indictment. The elementary facts are that Luther's late-life

28 See a summary of recent literature in E W Gritsch, Martin Luther's Anti-Semitism: against his better judgment (Grand Rapids, MI, 2012). 
railings against the Jews were quite in contrast to his earlier solicitude for the Jews, and quite in keeping with a millennium and more of vicious anti-Judaism and anti-Semitism in the Christian tradition. Luther certainly added his ample share of vitriol to this Christian tradition of anti-Semitism, and for that he deserves ample condemnation - doubly so, given that he knew that his words would inspire his followers. But Luther's words were not as harsh as those of many other Protestant, Catholic and Orthodox Christians before and after him who condemned the Jews and called for all manner of savage abuses against them. And Luther did not act on his words in a way that many Christians before him had done, and after him would do in their many campaigns of persecution, ghettoisation, ostracism and plain slaughter of the Jews.

To connect Luther to the horrors of the Holocaust is not only to strain elementary facts but also to strain elementary law. The criminal law of homicide in most Western jurisdictions provides that a defendant can be indicted for homicide only if the victim dies within a year and a day of that defendant's actions. This rule sometimes produces outrageous decisions at the margins: when victims dies on day 367 or shortly thereafter, or when defendants glory in their escape from liability by the mere accident of chronology. But the point of having this clear rule about causation is for a community to have closure. Nearly four hundred years elapsed between Luther's horrible sermon and the Nazis' horrible actions.

Moreover, an indictment for homicide depends on proof of a clear causal chain between the defendant's culpable action and the victim's ultimate death. The defendant's action must be the cause-in-fact of the victim's death - an action without which the death would not have occurred. The defendant's conduct must also be the proximate cause of the victim's death - close enough in time, space and foreseeability, without intervening conduct by third parties. It is unquestionable that Luther's late-life railings against the Jews were a link in the chain of causation that ultimately brought on the Holocaust. But it was but one link in a causal chain of many thousands of links, and was far removed in time, space and foreseeability from the actual horrors of the Holocaust.

I do not pass this judgment lightly. My family suffered massive losses during the Nazi occupation of the Netherlands, and my parents, aunts and uncles still carry deep scars on their bodies, minds and souls from the savagery, fear and deprivation that were visited on them in those long years of occupation. Perhaps the causal period for genocide, unlike that for homicide, should be infinite, not limited to a year and a day. Perhaps long chains of causation should be used to hang in memory, not to exonerate in casuistry, all those Christian hate-mongers against the Jews, however distant in time and cause from the actual events of the Holocaust. Perhaps the counsel of emotion is 
better than the counsel of law to deal with so evil a tragedy. Perhaps so. But for all his rhetorical braggadocio, I think Luther would have been as horrified as any of us to see what the Holocaust had wrought. In the hundred-plus thick volumes of his writings, there is precious little to indicate that he would have condoned diabolical savagery of this proportion.

Luther did know political evil in his day, albeit nothing on the scale of the Holocaust. Indeed, it was in response to that evil that he crafted his greatest hymn, 'A Mighty Fortress Is Our God'. His words in this hymn capture many of the convictions at the core of his dialectical theology: the contrasts between Satan and Christ, body and soul, works and faith, folly and truth, despair and hope, death and life, the mortality of the earthly kingdom and the eternity of the heavenly kingdom. They also capture his abiding faith that God and His Word ultimately remain in charge of both kingdoms, even if the devil and his human minions temporally vie for power in the earthly kingdom. This hymn is perhaps the best response to Luther's own failings and to the failings of countless Protestants after him. So, it will get the last word:

A mighty Fortress is our God,

A Bulwark never failing;

Our Helper he amid the flood

Of mortal ills prevailing:

For still our ancient foe

Doth seek to work us woe;

His craft and power are great,

And, armed with cruel hate,

On earth is not his equal.

Did we in our own strength confide,

Our striving would be losing;

Were not the right man on our side,

The man of God's own choosing:

Dost ask who that may be?

Christ Jesus, it is he;

Lord Sabaoth his Name,

From age to age the same,

And he must win the battle.

And though this world, with devils filled,

Should threaten to undo us;

We will not fear, for God hath willed

His truth to triumph through us:

The prince of darkness grim,

We tremble not for him; 
His rage we can endure,

For lo! his doom is sure,

One little word shall fell him.

That word above all earthly powers,

No thanks to them, abideth;

The Spirit and the gifts are ours

Through him who with us sideth:

Let goods and kindred go,

This mortal life also;

The body they may kill:

God's truth abideth still,

His kingdom is for ever. 